\title{
INFORMASI ASIMETRI DAN SENJANGAN ANGGARAN PADA PERGURUAN TINGGI DI YOGYAKARTA
}

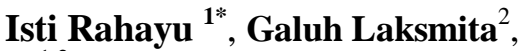 \\ ${ }^{1,2}$ Universitas Islam Indonesia \\ *Korespondensi: isti_rahayu@ uii.ac.id
}

\begin{abstract}
The purpose of this research is to examine the effect of budgetary participation and job involvement to the budgetary slack, and examine the role of asymmetry information as a moderating variable. Research sample are structural employees that involved in budgeting process at university in Yogyakarta. The data used in this research is primary data, and this research used a regression analysis test for developing the hypothesis framework. The findings in this research are: 1) Budgetary participation has positive effect on the budgetary slack. 2) Job involvement has positive effect on budgetary slack. 3) Asymmetry Information has not a positive effect on the relationship between budgetary participation with the budgetary slack. 4) Asymmetry Information has not a positive effect on the relationship between job involvement with budgetary slack.
\end{abstract}

Keywords: budgetary participation, job involvement, asymetry information, and budgetary slack

\begin{abstract}
ABSTRAK
Penelitian ini bertujuan untuk menguji pengaruh partisipasi anggaran dan keterlibatan kerja terhadap senjangan anggaran, dan menguji peran variabel informasi asimetri dalam menguatkan pengaruh partisipasi anggaran dan keterlibatan kerja terhadap senjangan anggaran. Pengujian dilakukan menggunakan data primer dengan sampel 51 penanggungjawab unit pertanggungjawaban pada perguruan tinggi swasta di Yogyakarta.

Pengujian data dilakukan menggunakan analisis regresi. Hasil penelitian menunjukkan terdapat pengaruh positip partisipasi anggaran terhadap senjangan anggaran, terdapat pengaruh positip keterlibatan kerja terhadap senjangan anggaran. Namun penelitian ini tidak berhasil membuktikan peran asimetri informasi dalam menguatkan pengaruh partisipasi anggaran dan keterlibatan kerja terhadap senjangan anggaran.

Penelitian ini memiliki implikasi bagi manajemen perguruan tinggi agar memperhatikan proses penyusunan anggaran yang dilakukan secara partisipatif, maupun keterlibatan yang tinggi dari penyusun anggaran, dengan ak menggunakan anggaran sebagai satu-satunya alat untuk mengukur kinerja. Dengan demikian akan tersusun anggaran yang optimal dan tidak memotivasi penyusun anggaran melakukan senjangan anggaran.
\end{abstract}

Kata Kunci: Partisipasi Anggaran, Keterlibatan Kerja, Informasi Asimetri, Senjangan Anggaran. DOI: $10.20885 /$ jabis.vol17.iss1.art4

\section{PENDAHULUAN}

Organisasi merupakan kumpulan orang yang bekerja sama untuk mewujudkan suatu tujuan. Orang bergabung dalam organisasi pada dasarnya karena ia ingin mewujudkan tujuan yang tidak mungkin dicapai melalui usahanya sendiri. Organisasi dikelola oleh hierarchy of managers, dari yang paling tinggi (CEO), manager unit bisnis, manajer unit fungsional dan manager subunit dibawahnya sesuai struktur organisasi. Manager di seluruh level harus memastikan bahwa orang-orang yang menjadi tanggungjawabnya mengimplementasikan strategi organisasi untuk mencapai tujuan dengan melakukan proses pengendalian manajemen. Proses pengendalian manajemen diawali dengan proses 
perumusan strategi, proses penerapan program, proses penyusun anggaran dan evaluasi. Anggaran merupakan komponen yang sangat penting bagi perusahaan.

Anggaran bukan hanya rencana fungsional mengenai biaya dan pendapatan dalam suatu pusat pertanggungjawaban, tetapi juga berfungsi sebagai alat pengendalian, koordinasi, komunikasi, evaluasi kinerja serta motivasi. Proses penyusunan anggaran dapat dilakukan secara top down maupun bottom up (partisipasi). Pada proses penyusunan secara bottom up, proses penyususnan anggaran pada dasar nya merupakan proses penetapan peran. Dalam hal ini setiap manajer di dalam organisasi diberi peran untuk melaksanakan kegiatan pencapaian sasaran yang ditetapkan dalam anggaran. Agar sasaran dapat dicapai manajer menengah dan bawah biasanya ikut berpartisipasi dalam perancangan anggaran, sehingga anggaran yang disusun secara bottom up dikenal juga sebagai anggaran partisipatip. . Dengan berpartisipasi, manajer merasa dilibatkan egonya tidak sekedar dilibatkan dalam kerja sehingga diharapkan akan mendorong moral kerja dan inisiatip para manajer. Partisipasi juga akan mengurangi tekanan dan kegelisahan, karena pihak yang berpartisipasi dalam penetapan anggaran tahu bahwa anggaran tersebut rasional dan dapat dicapai, sehingga mereka tidak merasa terpaksa untuk mencapai sasaran yang telah ditetapkan (Rahayu 1999).

Dalam penyusunan anggaran yang dilakukan secara partisipatip akan melibatkan manajer level bawah hingga manajer level atas agar keseluruhan manajer dapat melaksanakan kinerjanya. Anggaran yang disusun dengan pendekatan partisipatif tidak hanya memberikan dampak positip berupa peningkatan kinerja manajer karena termotivasi oleh anggaran yang mereka susun sendiri dan digunakan sebagai dasar penilaian kinerja, namun juga menimbulkan dampak negatip. Dampak negatip penyusunan anggaran yang dilakukan secara partisipatip antara lain berupa waktu penyusunan yang lebih lama dibandingkan jika menggunakan pendekatan top down, hasil diskusi dimungkinkan akan didominasi pihak yang dominan, maupun kemungkinan unit penyusun anggaran mengusulkan anggaran yang tidak sesuai dengan yang seharusnya/yang ideal atau terjadi senjangan (slack) anggaran.

Dengan melakukan senjangan anggaran maka kinerja para manajer akan terlihat bagus karena dapat mencapai target anggaran yang telah dibuat. Salah satu faktor yang menyebabkan senjangan anggaran yaitu keterlibatan kerja. Manajer dengan tingkat keterlibatan kerja yang tinggi akan memiliki kecenderungan yang lebih tinggi pula untuk menciptakan senjangan anggaran. Manajer merasa bertanggungjawab atas keputusan yang telah mereka buat sehingga akan berusaha mencapai target tersebut, dengan kemungkinan melakukan senjangan anggaran.

Penelitian tentang senjangan anggaran telah dilakukan antara lain oleh Sugiwardani (2012) yang menemukan bahwa partisipasi anggaran mempunyai pengaruh positip terhadap slack anggaran. Pello (2014) menemukan bahwa asimetri informasi dan locus of control berpengaruh negatif pada hubungan penganggaran partisipatif dengan senjangan anggaran. Anggasta dan Murtini (2014) menemukan asimetri informasi bukan menjadi faktor yang dapat memperkuat pengaruh partisipasi anggaran, 
penekanan anggaran, dan komitmen organisasi dalam menciptakan senjangan anggaran. Ardan ari dan Putra (2014) menunjukkan bahwa partisipasi penganggaran berpengaruh negatif terhadap budgetary slack, sedangkan asimetri informasi berpengaruh positif terhadap budgetary slack.

Berdasarkan hasil penelitian yang tidak konsisten dan penelitian-penelitian yang telah dilakukan lebih banyak difokuskan pada perusahaan yang berorientasi laba, maka penelitian tentang senjangan anggaran dilakukan kembali dengan obyek penelitian perguruan tinggi swasta di Yogyakarta. Perguruan tinggi merupakan organisasi nirlaba, namun demikian tetap memerlukan anggaran untuk mengukur kinerja keuangannya. Sebagaimana disebutkan dalam Halim, A., Tjahjono dan Husein (2009), walaupun kinerja keuangan tidak merupakan tujuan dominan pada organisasi nirlaba, tetapi tujuan dari aspek keuangan tetap perlu karena tanpa pendapatan yang sedikit melebihi biaya sulit bagi suatu organisasi untuk bertahan hidup.

Senjangan anggaran yang terjadi akan mengakibatkan perguruan tinggi tidak memiliki alat perencanaan, alat koordinasi maupun alat penilaian kinerja yang optimal. Penelitian ini bertujuan untuk mendapatkan bukti empiris pengaruh partisipasi anggaran dan keterlibatan kerja terhapan senjangan anggaran, serta pengaruh asimetri informasi sebagai penguat pengaruh partisipasi dan keterlibatan kerja terhadap senjangan anggaran.

\section{TINJAUAN PUSTAKA dan PENGEMBANGAN HIPOTESIS}

\section{Resource-based theory}

Resource-based theory (RBT) merupakan teori mengenai perusahaan yang memandang bahwa sebab perusahaan berdiri yaitu memberikan keunggulan daya saing, melalui sumberdaya yang dimiliki perusahaan. Wernerfelt dalam penelitian Solikhah (2010) menjelaskan bahwa menurut pandangan Resource-Based Theory, perusahaan memperoleh keunggulan kompetitif dan kinerja keuangan yang baik dengan cara memiliki, menguasai dan memanfaatkan aset - aset strategis yang penting. Aset-aset strategis tersebut termasuk aset berwujud maupun aset tak berwujud berupa : (1) Modal sumber daya fisik (teknologi, gedung, peralatan), (2) Modal sumber daya manusia (pelatihan, pengalaman, wawasan), (3) Modal sumber daya organisasi (struktur formal).

Dari penjelasan tersebut, menurut teori RBT, tujuan perusahaan akan bisa dicapai dengan menggunakan sumberdaya yang dimiliki. Proses penyusunan anggaran merupakan proses untuk mengalokasikan sumberdaya agar diperoleh hasil yang optimal. Proses penyusunan anggaran merupakan proses penyusunan rencana kerja jangka pendek, yang dalam perusahaan berorientasi laba, pemilihan rencana kerja didasarkan atas dampak rencana kerja tersebut terhadap laba (Mulyadi, 1997)

Laba merupakan tujuan utama dari organisasi bisnis. Berbeda dengan organisasi bisnis, organisasi nirlaba termasuk perguruan tinggi tidak bertujuan mencari laba, namun anggaran tetap diperlukan bagi organisasi nirlaba. Anggaran merupakan alat pengendalian manajemen yang paling penting dalam 
organisasi nirlaba, baik anggaran pendapatan maupun anggaran pengeluaran (Halim, A., Tjahjono dan Husein 2009).

\section{Aspek Perilaku dalam Penyusunan Anggaran Partisipatif}

Penyusunan anggaran merupakan salah satu tahap manajemen strategik, maka dari itu anggaran sangat diperlukan dalam organisasi bisnis maupun organisasi nirlaba untuk alat pengukur kinerja mereka. Seperti yang telah disebutkan dalam Mulyadi (1997) bahwa anggaran merupakan rencana aktivitas yang akan menjadi pedoman untuk melakukan serangkaian aktivitas tertentu di masa yang akan datang. Pada akhir periode akan dilakukan pengevaluasian antara anggaran dan realisasinya sehingga kinerja perusahaan dapat diukur.

Anggaran merupakan rencana kuantitatip yang dinyatakan secara moneter. Tujuan utama penyusunan anggaran yaitu : (1) untuk menyesuaikan rencana strategis, (2) untuk membantu mengoordinasikan aktivitas dari beberapa organisasi, (3) untuk menugaskan tanggung jawab kepada manajer, untuk mengotorisasi jumlah yang berwenang untuk mereka gunakan, dan untuk menginformasikan kepada mereke tentang kinerja yang diharapkan dari mereka, dan (4) untuk memperoleh komitmen yang merupakan dasar untuk mengevaluasi kinerja aktual manajer (Anthony dan Govindarajan 2007).

Ada banyak manfaat yang didapat oleh perusahaan dari program penganggaran sebagaimana dinyatakan oleh Garrison, R. H., Noreen dan Brewer (2013) yaitu : (1) Anggaran merupakan alat komunikasi bagi rencana menejemen kepada seluruh organisasi. (2) Anggaran memaksa manajer untuk memikirkan dan merencanakan masa depan. Tanpa penyusunan anggaran, maka akan terlalu banyak manajer yang harus menghabiskan waktunya untuk mengatasi berbagai masalah darurat. (3) Proses penganggaran merupakan alat alokasi sumber daya pada berbagai bagian dari organisasi agar dapat digunakan seefektif mungkin. (4) Proses penganggaran dapat mengungkap adanya potensi masalah sebelum masalah itu terjadi. (5) Anggaran mengkoordinasikan aktivitas seluruh organisasi dengan cara mengintegrasikan rencana dari berbagai bagian. Penganggaran ikut memastikan agar setiap orang dalam organisasi menuju tujuan yang sama. (6) Anggaran menentukan tujuan dan sasaran yang dapat dijadikan acuan untuk mengevaluasi kinerja selanjutnya. (7) Secara berkala, kinerja keuangan sesungguhnya dibandingkan dengan anggaran dan selisihnya dianalisis dan dijelaskan.

Proses penyusunan anggaran dapat dilakukan melalui pendekatan bottom-up, top-down, dan campuran. Oleh karena anggaran merupakan sistem perencanaan yang dilaksanakan dalam suatu organisasi, tentunya sistem ini akan memiliki dampak perilaku terhadap pihak-pihak yang terkait. Penyusunan anggaran dengan cara top-down memiliki akibat negatif yaitu target yang susah dicapai, namun juga memili aspek positip yaitu waktu penyusunan yang cepat. Disisi lain anggaran yang 
disusun secara partisipasi (bottom up) akan berdampak positif bagi perusahaan karena dapat meningkatkan rasa kesatuan dan kerjasama seluruh manejer untuk mencapai tujuan perusahaan.

Perancangan anggaran secara partisipatif telah sejak lama memperoleh perhatian peneliti. Rahayu (1999) mengemukakan bahwa penelitian tentang partisipasi anggaran diawali oleh Coch dan French pada tahun 1948 yang menemukan bahwa produktifitas karyawan meningkat setelah diijinkan untuk berpartisipasi dalam pembuatan keputusan tentang perubahan metode dan tugas. Dengan penyusunan anggaran secara partisipatif diharapkan kinerja para manajer akan meningkat. Hal ini didasarkan pada pemikiran bahwa ketika suatu standar yang dirancang secara partisipatif disetujui, maka karyawan akan menginternalisasi standar yang ditetapkan, dan karyawan juga memiliki rasa tanggungjawab pribadi untuk mencapainya karena mereka ikut terlibat dalam penyusunan. Internalisasi standar oleh para manajer akan meningkatkan efektifitas organisasi, karena konflik potensial antara tujuan individu dengan tujuan organisasi dapat dikurangi atau bahkan dihilangkan.

Garrison, R. H., Noreen dan Brewer (2013) menyatakan bahwa metode penyusunan anggaran yang paling baik adalah metode partisipatif (bottom up), di mana semua komponen yang ada dalam organisasi ikut dilibatkan dalam penyiapan anggaran. Partisipasi bawahan akan meningkatkan kebersamaan, menumbuhkan rasa memiliki, inisiatif untuk menyumbangkan ide, dan keputusan yang dihasilkan dapat diterima (Rahayu 1999). Selain itu partisipasi juga dapat mengurangi konflik potensial antara tujuan individu dengan tujuan organisasi sehingga kinerja bawahan meningkat. Melalui partisipasi, atasan dapat memperoleh informasi mengenai lingkungan yang sedang dan akan dihadapi. Namun, selain memiliki dampak positif, partisipasi anggaran juga memiliki dampak negatif, yaitu memunculkan senjangan anggaran. Rasa tertekan atas bisa tidaknya target tercapai, akan mempengaruhi bagaimana tingkat target yang akan dibuat.

Menurut Anthony dan Govindarajan (2007) pendekatan dari atas-ke-bawah (top-down) mengarah kepada kurangnya komitmen dari sisi pembuat anggaran dan hal ini membahayakan keberhasilan rencana tersebut. Sedangkan penyusunan anggaran dari bawah-ke-atas (bottom-up) kemungkinan besar akan menciptakan komitmen untuk mencapai tujuan anggaran, namun jika tidak dikendalikan dengan hati-hati, pendekatan ini dapat menghasilkan jumlah yang sangat mudah atau tidak sesuai dengan tujuan keseluruhan dari perusahaan. Penyusunan anggaran dengan cara top-down memiliki akibat negatif yaitu target yang susah dicapai, sedangkan bottom-up memiliki akibat negatif yaitu menimbulkan senjangan anggaran.

Senjangan anggaran merupakan perilaku yang disengaja dari penyusun anggaran dengan menurunkan pendapatan yang dianggarkan dan meningkatkan biaya yang dianggarkan. Senjangan anggaran menyajikan anggaran dengan tingkat kesulitan yang rendah, dengan cara merendahkan target pendapatan dan meninggikan target pengeluaran. 
Menurut Apriyadi (2011) faktor yang mendorong seorang manajer melakukan senjangan anggaran, yaitu: (1) Seringnya atasan atau manajamen tingkat atas mengubah atau memotong anggaran yang diusulkan. Biasanya seorang manajer menetapkan anggaran untuk divisinya dengan mempertimbangkan berbagai faktor baik dalam segi volume maupun keuntungan, tetapi setelah diajukan ke manajer puncak ternyata anggaran tersebut diubah tanpa mendiskusikan dengan bawahan. Oleh karena itu, para manajer mengantisipasi hal tersebut dengan melakukan senjangan anggaran, (2) Adanya ketidakpastian pasar, biasanya perkiraan volume produksi menjadi tidak tepat pada saat adanya persaingan yang tiba-tiba meningkat, dan jika tidak tersedia dana untuk mengatasi kondisi tersebut maka manajer akan cenderung menggunakan senjangan anggaran untuk memenuhi target keuntungannya. Apriyadi (2011) juga mengemukakan selain itu ada empat kondisi penting yang dapat menyebabkan terjadinya senjangan anggaran yaitu (1) Terdapat informasi asimetri antara manajemen tingkat bawah dengan atasan, (2) Kinerja manajer tidak pasti, (3) Manajer mempunyai kepentingan pribadi, (4) Konflik kepentingan antara manajemen tingkat bawah dengan atasan.

\section{Hipotesis Penelitian}

Pada perusahaan yang menggunakan anggaran sebagai alat ukur kinerja, manajer akan dianggap berhasil apabila mampu beroperasi sesuai anggaran yang ditetapkan, sebaliknya apabila tidak sesuai dengan target yang telah dibuat maka manajer dianggap tidak berhasil. Untuk memudahkan operasional berdasarkan anggaran, maka senjangan (slack) anggaran sering terjadi saat proses pembuatan anggaran. Hal ini dimaksudkan agar anggaran mudah dicapai sehingga manajer dinilai baik oleh atasannya. Partisipasi yang tinggi dalam proses penyusunan anggaran, memberikan kesempatan yang lebih besar kepada bawahan untuk melakukan senjangan. Ketika partisipasi rendah harapan bawahan untuk melakukan senjangan dibatasi, sehingga senjangan anggaran juga rendah. Penelitian sebelumnya yang dilakukan oleh Venusita (2008), Sugiwardani (2012), Anggasta dan Murtini (2014) menyimpulkan bahwa terdapat pengaruh signifikan penganggaran partisipatif terhadap senjangan anggaran dengan arah positif.

Ha1: Partisipasi anggaran berpengaruh positip terhadap senjangan anggaran

Para manajer dengan tingkat keterlibatan kerja yang tinggi akan memiliki kecenderungan yang lebih tinggi pula untuk menciptakan senjangan anggaran, sedangkan manajer yang memiliki tingkat keterlibatan kerja rendah, kurang memiliki kecenderungan untuk menciptakan senjangan anggaran karena mereka tidak mengidentifikasikan kerja mereka dan tidak peduli dengan pekerjaan mereka. Manajer yang memiliki keterlibatan kerja tinggi akan merasa bertanggungjawab atas pekerjaan mereka sehingga akan mendorong mereka untuk membuat anggaran yang mudah dicapai dengan melakukan 
senjangan anggaran. Venusita (2008), Ardan ari dan Putra (2014) menemukan bahwa keterlibatan kerja mempunyai pengaruh positif yang signifikan terhadap senjangan anggaran, yang artinya apabila semakin tinggi keterlibatan kerja maka semakin tinggi pula senjangan anggaran.

Ha2: Keterlibatan kerja berpengaruh positif terhadap senjangan anggaran

Senjangan anggaran dimungkinkan terjadi karena manajer pusat pertanggungjawaban yang dilibatkan dalam penyusunan anggaran dengan pendekatan partisipatif memiliki informasi lebih luas berkaitan dengan aktivitas yang dianggarkan dibandingkan manajemen level atas. Perbedaan informasi yang dimiliki memungkinkan anggaran diusulkan dengan jumlah yang lebih tinggi atau lebih rendah dari yang seharusnya dianggarakan dengan tujuan untuk mempermudah pencapaian anggaran (Pello, 2014). Pada proses penganggaran partisipatif, semakin besar perbedaan informasi yang dimiliki akan semakin memperbesar terjadinya senjangan anggaran. Hal ini terjadi karena atasan atau manajemen puncak yang memiliki informasi lebih sedikit berkaitan dengan aktivitas yang dianggarkan dibanding bawahan, akan lebih longgar dalam mereview usulan anggaran, yang mengakibatkan tuntutan atasan terhadap bawahan tentang pencapaian target anggaran menjadi lebih longgar dan sangat mudah dicapai oleh bawahan. Rahmiati (2013) dan Pello (2014) menyimpulkan bahwa informasi asimetri berpengaruh signifikan positif terhadap hubungan partisipasi anggaran dengan senjangan anggaran. Dari uraian logika dan penelitian sebelumnya, maka peneliti membuat hipotesis sebagai berikut

Ha3: Informasi asimetri menguatkan pengaruh partisipasi anggaran terhadap senjangan anggaran.

Keterlibatan kerja adalah rasa tanggungjawab yang dimiliki oleh seorang manajer atas tanggungjawabnya di perusahaan. Para manajer dengan tingkat keterlibatan kerja yang tinggi akan memiliki kecenderungan lebih tinggi untuk menciptakan senjangan anggaran dibandingkan manajer yang memiliki tingkat keterlibatan kerja rendah, karena manajer yang memiliki keterlibatan tinggi akan merasa tidak nyaman jika target yang diusulkan tidak tercapai. Manajer yang memiliki keterlibatan kerja tinggi umumnya sangat konsern dengan pekerjaan yang dilakukan sehingga memiliki informasi yang sangat memadai berkaitan dengan aktivitas yang dianggarkan, dibandingkan manajer atas yang hanya memiliki informasi secara garis besar. Perbedaan informasi yang dimiliki memungkinkan manajer bawah menyusun anggaran yang mudah dicapai. Hasil penelitian Pello (2014) menyatakan bahwa informasi asimetri berpengaruh positif dan signifikan terhadap senjangan anggaran. Sedangkan Venusita (2008), Ardan ari dan Putra (2014) menemukan bahwa keterlibatan kerja mempunyai pengaruh positif terhadap senjangan anggaran. Dari uraian logika dan penelitian terdahulu, peneliti membuat hipotesis sebagai berikut

Ha4: Informasi asimetri menguatkan pengaruh keterlibatan kerja terhadap senjangan anggaran. 


\section{Model Penelitian}

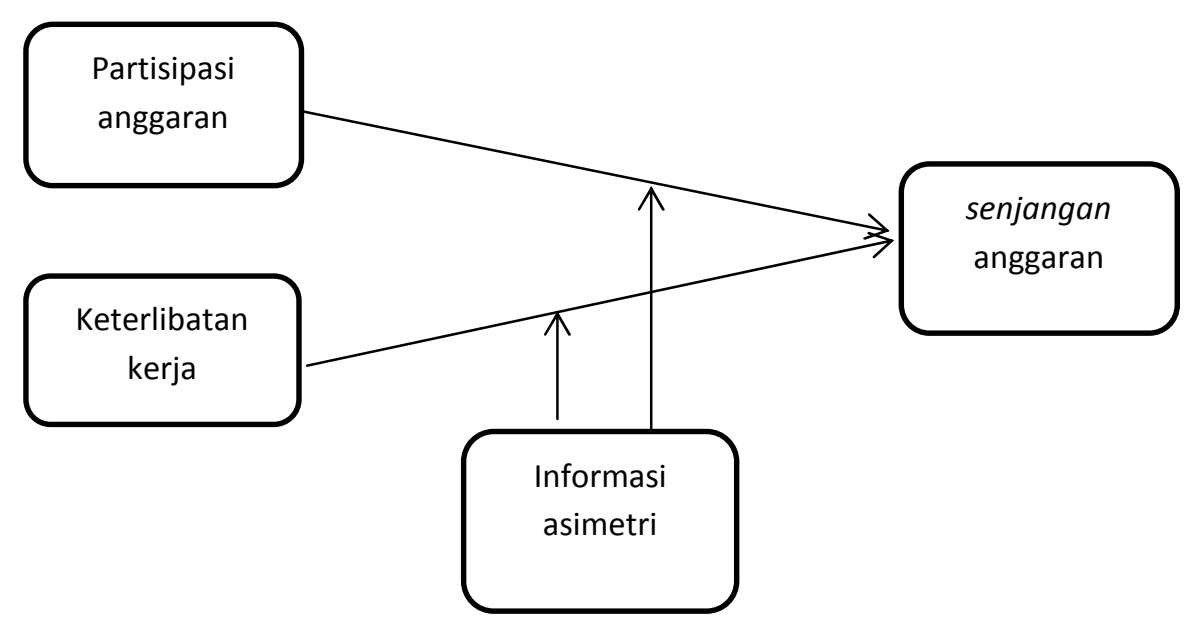

Gambar 1: Model penelitian

\section{METODE PENELITIAN}

\section{Populasi dan Sampel}

Populasi dalam penelilitian ini adalah Perguruan Tinggi Swasta di Daerah Istimewa Yogyakarta. Penentuan pemilihan sampel dalam penelitian ini dengan menggunakan teknik purposif dengan kriteria: perguruan tinggi swasta berbentuk universitas dan menyusun anggaran secara partisipatif.

Pengambilan data dilakukan secara primer dengan menyebarkan kuesioner kepada penganggungjawab unit pertanggungjawaban di perguruan tinggi terkait, dan terlibat dalam penyusunan anggaran. Kuesioner terdiri dari 2 bagian yaitu identitas responden dan pernyataan mengenai parisipasi anggaran, keterlibatan kerja, informasi asimetri dan senjangan anggaran. Kuesioner terdiri lima pilihan jawaban yaitu:" Sangat Setuju" (SS) diberi nilai 5, "Setuju" (S) diberi nilai 4, "Ragu-Ragu" (RR) diberi nilai 3, "Tidak Setuju" (TS) diberi nilai 2 dan nilai 1 untuk "Sangat Tidak Setuju" (STS). Khusus untuk variabel informasi asimetri responden diminta memilih pihak yang lebih memiliki informasi dengan alteratif pilihan $1=$ atasan, $2=$ cenderung atasan, $3=$ sama, 4=cenderung saya, $5=$ saya. 


\section{Variabel Penelitian}

Terdapat empat variabel dalam penelitian ini, yaitu satu variabel independen: Senjangan Anggaran, dua variabel independen, yaitu: Partisipasi Anggaran dan Keterlibatan Kerja, serta satu variabel moderasi: Informasi Asimetri.

\section{Partisipasi Anggaran}

Partisipasi anggaran merupakan keikutsertaan karyawan dalam penyusunan anggaran. Untuk mengukur variabel partisipasi anggaran digunakan kuesioner yang diambil dari Milani yang dikutip dari Asnawi (1997) dengan enam item pertanyaan: (1) Proses penyusunan anggaran membutuhkan keikutsertaan saya, (2) Proses penyusunan anggaran sangat membutuhkan pendapat saya, (3) Proses penyusunan anggaran akan selesai apabila saya telah merasa puas dengan anggaran tersebut, (4) Saya sering memberikan pendapat atau usulan kepada atasan saya secara sukarela, (5) Saya memiliki pengaruh yang besar dalam penetapan anggaran akhir, (6) Atasan saya sering meminta pendapat atau usulan pada saat anggaran sedang disusun.

\section{Keterlibatan Kerja}

Keterlibatan kerja menggambarkan seberapa jauh hubungan karyawan dengan pekerjaan mereka. Variabel keterlibatan kerja diukur menggunakan kuesioner Kanungo sebagaimana dikutip dari Risniora (2005) dengan enam butir pertanyaan: (1) Pekerjaan bagi saya mempunyai arti lebih dari sekedar uang, (2) Kepuasan utama dalam hidup saya datang dari pekerjaan, (3) Saya akan tetap bekerja walaupun saya tidak memerlukan uang, (4) Hal terpenting yang terjadi dalam hidup saya berkaitan dengan pekerjaan saya, (5) Saya akan terus bekerja lembur untuk menyelesaikan pekerjaan, walaupun itu tidak dibayar

\section{Informasi Asimetri}

Informasi asimetri adalah ketidakseimbangan informasi yang dimiliki karyawan dengan informasi yang dimiliki manajer. Variabel informasi asimetri diukur menggunakan kuesioner yang dikembangkan oleh Dunk sebagaimana dikutip Apriyadi (2011). Kuesioner terdiri dari enam item pertanyaan: (1) Dibandingkan dengan atasan anda, siapa yang memiliki informasi lebih baik mengenai kegiatan yang dilakukan dalam unit saudara?, (2) Dibandingkan dengan atasan anda, siapa yang lebih mengetahui hubungan input-output yang ada dalam unit saudara?, (3) Dibandingkan dengan atasan anda, informasi siapa yang lebih dapat dipercayai mengenai potensi kinerja unit saudara?, (4) Dibandingkan dengan atasan anda, siapa yang lebih mengetahui mengenai teknik kerja unit saudara?, (5) Dibandingkan dengan atasan anda, siapa yang lebih mampu menilai pengaruh faktor eksternal 
dalam unit saudara?, (6) Dibandingkan dengan atasan anda, siapa yang lebih memahami apa yang dapat dicapai unit saudara?

\section{Senjangan Anggaran}

Senjangan anggaran adalah perbedaan jumlah anggaran yang disusun dengan estimasi atau target terbaik perusahaan. Untuk mengukur variabel senjangan anggaran digunakan kuesioner yang dikembangkan oleh Dunk yang dikutip dari Apriyadi (2011) dengan enam item pertanyaan: (1) Penentuan standar dalam anggaran menghasilkan produktivitas tinggi dalam unit saya, (2) Target anggaran pada unit saya dapat dicapai dengan mudah, (3) Saya harus lebih memperhatikan penggunaan biaya-biaya dalam unit saya karena adanya batasan anggaran, (4) Anggaran dalam unit saya tidak banyak persyaratannya, (5) Target anggaran tidak menyebabkan saya menghubungkannya dengan perbaikan (6) Target perusahaan dalam anggaran sulit dicapai.

\section{Metoda Analisis Data}

Sebelum dilakukan uji model, terlebih dahulu dilakukan uji validitas untuk mengetahui tingkat kevalidan instrumen penelitian, dan uji reliabilitas untuk mengetahui sejauh mana hasil dapat dipercaya dan bisa dipertanggungjawabkan konsistensinya. Selanjutnya dilakukan uji regresi dengan model:

$\mathrm{Y}=\mathrm{a}+\mathrm{b} 1 \mathrm{X} 1+\mathrm{b} 2 \mathrm{X} 2+\mathrm{b} 3 \mathrm{X} 3+\mathrm{b} 4(\mathrm{X} 1 \mathrm{X} 3)+\mathrm{b} 5(\mathrm{X} 2 \mathrm{X} 3)+\mathrm{e}$

Dimana:

$\mathrm{Y} \quad=$ senjangan anggaran

A $\quad=$ Nilai intercept $/$ constant

b1-b5 = Koefisien regresi

$\mathrm{e} \quad=$ eror

$\mathrm{X} 1 \quad=$ partisipasi penganggaran

$\mathrm{X} 2=$ keterlibatan kerja

$\mathrm{X} 3 \quad=$ informasi asimetri

Berdasarkan hasil regresi kemudian dilakukan uji t untuk menunjukkan seberapa jauh pengaruh satu variabel independen secara individual dalam menerangkan variasi variabel dependen dengan taraf signifikansi ( $\alpha$ ) sebesar 5\%.

\section{HASIL DAN PEMBAHASAN}

Responden dalam penelitian ini adalah pegawai struktural yang terlibat dalam penyusunan anggaran pada perguruan tinggi swasta di Daerah Istimewa Yogyakarta. Kuesioner yang disebar 
dalam penelitian ini sebanyak 60 kuesioner, dan yang kembali sebanyak 51 kuesioner, dengan tingkat pengembalian kuesioner sebanyak $85 \%$.

\section{Deskripsi Responden}

Diskripsi data penelitian berdasarkan latar belakang pendidikan para responden dapat dilihat di tabel di bawah ini.

Tabel 1: Pendidikan Terakhir Responden

\begin{tabular}{ccc}
\hline Pendidikan & Jumlah & Persentase \\
\hline S3 & 2 & $3,9 \%$ \\
\hline S2 & 2 & $3,9 \%$ \\
\hline S1 & 13 & $25,5 \%$ \\
\hline D3 & 15 & $29,4 \%$ \\
\hline SLTA & 19 & $37,3 \%$ \\
\hline Total & 51 & $100 \%$
\end{tabular}

Sumber: Data diolah 2015

Dari diskripsi diatas terlihat bahwa minimal pendidikan personal yang terlibat dalam penyusunan anggaran adalah SLTA, namun juga ada yang berpendidikan S3. Hal ini dapat dipahami karena dalam penyusunan anggaran partisipatif melibatkan penanggungjawab unit pertanggungjawaban dari terendah sampai tertinggi. Jika dilihat dari gender, diskripsi responden sebagai berikut:

Tabel 2: Responden Berdasarkan Gender

\begin{tabular}{ccc}
\hline Kriteria & Jumlah & Persentase \\
\hline Laki-laki & 31 & $60,78 \%$ \\
Perempuan & 20 & $39,22 \%$ \\
\hline Total & 51 & $100 \%$
\end{tabular}

Sumber: Data diolah 2015

Dari diskripsi diatas terlihat bahwa penyusunan anggaran didominasi oleh laki-laki sebanyak $60,78 \%$, sedangkan wanita yang terlibat dalam penyusunan anggaran $39,22 \%$.

Sedangkan kalau dilihat dari umur, maka responden didominasi usia relatif muda dibawah 40 tahun. 
Tabel 3: Responden Berdasarkan Umur Responden

\begin{tabular}{ccc}
\hline Kriteria & Jumlah & Persentase \\
\hline $31-35$ & 14 & $27,45 \%$ \\
\hline $36-40$ & 26 & $50,98 \%$ \\
\hline $41-45$ & 11 & 21,57 \\
\hline Total & 51 & $100 \%$
\end{tabular}

Sumber: Data diolah 2015

\section{Analisis Deskrisi Variabel}

Analisis deskriptif dalam penelitian ini digunakan untuk menggambarkan ringkasan data-data penelitian yang terdiri dari skor minimum, skor maksimum, rata-rata (mean) dan standar deviasi.

Tabel 4: Statistik Deskriptif Variabel

\begin{tabular}{cccccc} 
Var & N & Minimum & Maximum & Mean & Std. Deviasi \\
\hline PA & 51 & 12,00 & 30,00 & 18,9412 & 3,93147 \\
KK & 51 & 12,00 & 27,00 & 20,4118 & 3,78511 \\
IA & 51 & 6,00 & 30,00 & 14,7255 & 6,12561 \\
SA & 51 & 12,00 & 28,00 & 21,1765 & 4,74850 \\
\hline
\end{tabular}

Sumber: Data diolah 2015

Berdasarkan tabel tersebut, partisipasi anggaran mempunyai skor 12-30 sehingga diperoleh skor rata-rata sebesar 18,9412 yang mana apabila dibagi dengan jumlah item pertanyaan sebanyak 6 item akan menghasilkan skor rata-rata sebesar 3,157, ini berarti rata-rata responden memberikan penilaian pada skor 3-4 pada tiap item pertanyaan.

Pada keterlibatan kerja, skor yang dihasilkan adalah 12-27 sehingga diperoleh skor rata- rata sebesar 20,4118 yang mana apabila dibagi dengan jumlah item pertanyaan sebanyak 6 item akan menghasilkan skor rata-rata sebesar 3,402, ini berarti rata-rata responden memberikan penilaian pada skor 3-4 pada tiap item pertanyaan.

Pada informasi asimetri, skor yang dihasilkan adalah 6-30 sehingga diperoleh skor rata-rata sebesar 14,7255 yang mana apabila dibagi dengan jumlah item pertanyaan sebanyak 6 item akan menghasilkan skor rata-rata sebesar 2,454 , ini berarti rata-rata responden memberikan penilaian pada skor 2-3 pada tiap item pertanyaan. 
Pada slack anggaran, skor yang dihasilkan adalah 12-28 sehingga diperoleh skor rata-rata sebesar 21,1765 yang mana apabila dibagi dengan jumlah item pertanyaan sebanyak 6 item akan menghasilkan skor rata-rata sebesar 3,529, ini berarti rata-rata responden memberikan penilaian pada skor 3-4 pada tiap item pertanyaan.

\section{Hasil Uji Validitas, Reliabilitas, dan Normalitas}

Untuk mengetahui sejauh mana ketepatan alat ukurdalam menguji obyek yang diukur, dilakukan uji validitas dan reiabilitas. Meskipun instrumenpenelitian telah dipergunakan pada penelitian-penelitian sebelumnya, namun uji validitas dan reliabilitas tetap dilakukan karena dimungkinkan hasil validitas dan reliabilitas berbeda dengan penelitian terdahulu.

Berdasarkan hasil pengujian dari semua pertanyaan dalam kuesioner maka pertanyaan tentang Partisipasi Anggaran, terdiri dari PA1 sampai dengan PA6 memiliki nilai $r$ hitung lebih dari $r$ $\mathrm{n}=51$ dan $\alpha=5 \%$ yaitu 0,276 sehingga item-item pertanyaan tersebut dikatakan Valid. Pertanyaan tetang Keterlibatan Kerja, yaitu KK1 sampai dengan KK6 memiliki nilai r hitung lebih dari $r$ tabel untuk $\mathrm{n}=51$ dan $\alpha=5 \%$ yaitu 0,276 sehingga item-item pertanyaan tersebut dikatakan Valid. Pertanyaan tentang Asimetri Informasi yang terdiri dari IA1 sampai dengan IA6 memiliki nilai $r$ hitung lebih dari $r$ tabel untuk $\mathrm{n}=51$ dan $\alpha=5 \%$ yaitu 0,276 sehingga item-item pertanyaan tersebut dikatakan Valid. Sedangkan hasil uji validitas untuk variabel Slack Anggaran yang terdiri dari pertanyaan SA1 sampai dengan SA6 memiliki nilai $r$ hitung lebih dari $r$ tabel untuk $n=51$ dan $\alpha=5 \%$ yaitu 0,276 sehingga item-item pertanyaan tersebut dikatakan Valid.

Uji reliabilitas dilakukan dengan melihat koefisien cronbach`s alpha Hasil uji reliabilitas yang digunakan untuk mengetahui sejauh mana hasil dapat dipercaya, menunjukkan Pasrtisipasi Anggaran memiliki Koefisien Alpha 0,792, Keterlibatan Kerja memiliki koefisien Alpha 0,704, Informasi Asimetri memiliki koefisien alpha 0,918 dan Senjangan Anggaran memiliki koefisien Alpha 0,729. Dengan demikian semua variabel terpenuhi reliabilitasnya. Sumber:

Berdasarkan uji normalitas dengan kolmogorof smirnov, variabel memiliki distribusi normal dengan tingkat sig $>0.05$.

\section{Hasil Uji Koefisien Determinasi}

Uji koefisien determinasi digunakan untuk mengetahui seberapa besar pengaruh variabel bebas terhadap variabel tetapnya dalam satuan persentasi. Hasil uji koefisien determinan dapat dilihat dalam tabel di bawah ini: 
Tabel 5: Hasil Uji Koefisien Determinasi

\begin{tabular}{ccccc}
\hline Model & $\mathrm{R}$ & $\mathrm{R}$ Square & Adjusted R Square & Std. Error of the Estimate \\
\hline 1 & 0,790 & 0,623 & 0,582 & 3,07147 \\
\end{tabular}

Sumber: Data Diolah 2015

Nilai koefisien determinasi (Adjusted $R$ Square) sebesar 0,582 yang menunjukkan bahwa sebesar 58,2\% senjangan anggaran dapat dijelaskan oleh partisipasi anggaran, keterlibatan kerja dan informasi asimetri, sisanya $41,8 \%$ dijelaskan oleh faktor lain di luar variabel yang tidak dimasukkan dalam penelitian ini.

\section{Hasil Pengujian Regresi}

Hasil pengujian regresi sebagai berikut:

\section{Tabel 6: Hasil Pengujian Regresi}

\begin{tabular}{lcl}
\hline \multicolumn{1}{c}{ Variabel } & B & Sig \\
\hline (Constant) & & \\
PA & $-24,417$ & 0,004 \\
KK & 1,269 & 0,001 \\
IA & 0,856 & 0,049 \\
PA_IA & 2,325 & 0,000 \\
KK_IA & $-0,54$ & 0,003 \\
\hline
\end{tabular}

Sumber: Data Diolah 2015

Berdasarkan hasil analisis regresi linier berganda yang terdapat di tabel 4.12, didapatkan nilai konstanta sebesar -24,417, koefisien regresi partisipasi anggaran sebesar 1,269, koefisien regresi keterlibatan kerja sebesar 0,856, koefisien informasi asimetri sebesar 2,325, koefisien regresi variabel pemoderasi yang merupakan interaksi antara partisipasi anggaran dengan informasi asimetri sebesar -0,54 dan koefisien regresi variabel pemoderasi yang merupakan interaksi antara keterlibatan kerja dengan informasi asimetri sebesar -0,47.

Dari hasil uji regresi, variabel partisipasi anggaran memiliki nilai sig. sebesar 0,001 lebih kecil dari $\alpha(0,05)$ dengan koefisien regresi positip 1,269, sehingga Ha1 diterima. Hal ini menunjukkan bahwa partisipasi anggaran berpengaruh positif terhadap senjangan anggaran, yang artinya semakin tinggi tingkat partisipasi anggaran maka semakin tinggi pula senjangan anggaran. Hasil ini membuktikan teori bahwa keterlibatan dalam penyususnan anggaran akan meningkatkan 
kemungkinan terjadinya senjangan anggaran karena penanggungjawab unit pertanggungjawaban khawatir tidak mampu mencapai apa yang telah ditargetkan. Hasil tersebut mendukung penelitian (Sugiwardani 2012), yang menyatakan bahwa partisipasi anggaran berpengaruh signifikan terhadap slack anggaran.

Variabel keterlibatan kerja memiliki nilai sig. sebesar 0,049 lebih kecil dari $\alpha(0,05)$ dengan koefisien regresi positip 0,856 , sehingga $\mathrm{Ha} 2$ diterima. Hal ini menunjukkan bahwa keterlibatan kerja berpengaruh positif terhadap senjangan anggaran. Semakin tinggi keterlibatan kerja maka semakin tinggi pula senjangan anggaran. Hasil tersebut mendukung penelitian Venusita (2008) dan Risniora (2005) yang menyatakan bahwa keterlibatan kerja berpengaruh secara positif dan signifikan terhadap senjangan anggaran. Semakin tinggi tigkat keterlibatan penyusun anggaran dalam melaksanakan pekerjaan, maka kemungkinan terjadinya senjangan anggaran juga semakin tinggi.

Variabel interaksi antara partisipasi anggaran dengan informasi asimetri memiliki nilai sig. sebesar 0,003 lebih kecil dari $\alpha(0,05)$ dengan koefisien regresi $-0,54$, sehingga Ha3 ditolak, Informasi asimetri tidak menguatkan pengaruh partisipasi anggaran terhadap senjangan anggaran, namun informasi asimetri justru menurunkan pengaruh partisipasi terhadap senjangan anggaran. Hasil tersebut tidak mendukung penelitian Apriyadi (2011) yang menyatakan bahwa informasi asimetri memiliki pengaruh terhadap slack anggaran. Arah negatif dalam penelitian ini yang berarti interaksi partisipasi anggaran dengan informasi asimetri justru menurunkan senjangan anggaran. Hal ini kemungkinan dikarenakan anggaran tidak digunakan sebagai satu-satunya alat untuk mengukur kinerja, sehingga penyusun anggaran tidak termotivasi melakukan senjangan anggaran meskipun mereka memiliki informasi yang lebih baik. Senjangan anggaran yang justru turun saat penyusun anggaran memiliki informasi yang lebih baik dibandingkan atasan, juga dimungkinkan terjadi karena penyusun anggaran/bawahan memiliki komitmen yang tinggi terhadap organisasi. Hasil penelitian ini mendukung penelitian Ardan ari and Putra (2014) yang menemukan bahwa informasi asimetri berpengaruh negatif terhadap hubungan antara partisipasi anggaran dan slack anggaran.

Variabel interaksi antara keterlibatan kerja dengan informasi asimetri memiliki nilai sig. 0,111 lebih besar dari $\alpha(0,05)$ dengan koefisien regresi $-0,47$, sehingga Ha4 ditolak. Dengan demikian informasi asimetri tidak menguatkan pengaruh keterlibatan kerja terhadap senjangan anggaran. Hasil tersebut tidak mendukung penelitian Apriyadi (2011) yang menyatakan bahwa informasi asimetri memiliki pengaruh terhadap slack anggaran. Penyebab tidak berpengaruhnya informasi asimetri terhadap hubungan antara keterlibatan kerja dengan senjangan anggaran dikarenakan karyawan telah mengenal sepenuhnya mengenai teknis pekerjaannya dan karyawan mempunyai pemahaman yang baik mengenai apa yang harus dicapai di area yang menjadi tanggung jawabnya, sehingga tidak khawatir target anggaran tidak tercapai. Tidak terbuktinya hipotesis juga dimungkinkan karena anggaran tidak digunakan sebagai satu satunya alat ukur kinerja, sehingga tidak memotivasi penyusun untuk melakukan senjangan anggaran. 


\section{KESIMPULAN}

Berdasarkan hasil pengolahan dan analisis data penelitian dapat disimpulkan bahwa partisipasi anggaran berpengaruh positif terhadap senjangan anggaran. Keterlibatan kerja juga berpengaruh positif terhadap senjangan anggaran. Namun penelitian tidak berhasil membuktikan informasi asimetri menguatkan pengaruh antara parisipasi anggaran terhadap senjangan anggaran. Interaksi partisipasi anggaran dengan informasi asimetri justru menurunkan senjangan anggaran. Hasil penelitian ini juga tidak dapat membuktikan Informasi asimetri menguatkan pengaruh keterlibatan kerja terhadap senjangan anggaran.

Hasil penelitian menunjukkan variabel Informasi Asimetri berpengaruh signifikan baik sebagai variabel independen maupun sebagai variabel moderasi. Hal ini menunjukkan bahwa variabel Informasi Asimetri merupakan variabel quasi moderasi yang dapat berperan sebagai variabel independen maupun variaber moderasi.

\section{SARAN}

Penelitian ini memiliki jumlah sampel yang relatif sedikit dikarenakan keterbatasan perolehan ijin menyebarkan kuesioner. Meski demikian peneliti berharap penelitian ini dapat tetap bermanfaat bagi pembacanya. Untuk penelitian berikutnya diharapkan untuk menambah jumlah sampel agar semakin mewakili populasi.

Masih terdapat variabel lain yang diduga mempengaruhi senjangan anggaran. Hal ini terlihat dari nilai adj $\mathrm{R}$ square sebesar 0,582 . Pada penelitian selanjutnya agar dimasukkan variabel lain yang diduga mempengaruhi senjangan anggaran, yaitu komitmen terhadap organisasi. Jika karyawan memiliki komitmen yang tinggi maka kemungkinan tidak akan menciptakan senjangan anggaran, meskipun memiliki kesempatan untuk melakukannya.

Manajemen perguruan tinggi agar memperhatikan proses penyusunan anggaran yang dilakukan secara partisipatif, maupun keterlibatan yang tinggi dari penyusun anggaran, karena berpotensi mengakibatkan terjadinya senjangan anggaran. Upaya untuk mencegah terjadinya senjangan anggaran dapat dilakukan dengan tidak menggunakan anggaran sebagai satu-satunya alat untuk mengukur kinerja, sehingga akan tersusun anggaran yang optimal.

\section{DAFTAR PUSTAKA}

Anggasta, and Murtini. 2014. "Determinan Senjangan Anggaran Denga Asimetri Informasi Sebagai Moderasi." Accounting Analisys Journal 3 (4): 513-23.

Anthony, R.N, and N Govindarajan. 2007. Management Control System. 12thed. New York: McGraw Hill. 
Apriyadi. 2011. "Pengaruh Informasi Asimetri Terhadap Hubungan Antara Anggaran Partisipatif Dengan Budgetary Slack.” Universitas Hasanudin.

Ardan ari, I, and Putra. 2014. "Pengaruh Partisipasi Penganggaran, Asimetri Informasi, Self Esteem Dan Budget Emphasis Pada Budgetary Slack." E-Journal Universitas Udayana 7 (3): 700-713.

Asnawi, Meinarni. 1997. "Partisipasi Anggaran, Komitmen Organisasi Dan Keterlibatan Pekerjaan Pengaruhnya Terhadap Senjangan Anggaran.” Gadjah Mada.

Garrison, R. H., Noreen, E. W., and P. C Brewer. 2013. Akuntansi Manajerial. 14thed. Jakarta: Salemba Empat.

Halim, A., Tjahjono, A., and M. F Husein. 2009. Sistem Pengendalian Manajemen. Edisi Revisi. Yogyakarta: Unit Penerbit dan Percetakan Sekolah Tinggi Ilmu Manajemen YKPN.

Mulyadi. 1997. Akuntansi Manajemen. Edisi 2. Yogyakarta: Bagian Penerbitan Sekolah Tinggi Ilmu Ekonomi YKPN.

Pello, Elisabeth V. 2014. "Pengaruh Asimetri Informasi Dan Locus of Control Terhadap Hubungan Antara Penggaran Partisipatif Dan Senjangan Anggaran.” E-Journal Universitas Udayana 6 (2): 287-305.

Rahayu, Isti. 1999. "Pengaruh Ketidakpastian Lingkungan Terhadap Partisipasi Anggaran." Jurnal Akuntansi Auditing Indonesia 3 (2): 123-33.

Rahmiati, E. 2013. "Pengaruh Partisipasi Anggaran Terhadap Senjangan Anggaran Dengan Asimetri Informasi Dan Komitmen Organisasi Sebagai Pemoderasi (Studi Empiris Pada Pemerintah Daerah Kota Padang)."

Risniora, Juan. 2005. "Pengaruh Partisipasi Anggaran Dan Keterlibatan Kerja Terhadap Senjangan Anggaran Dengan Komitmen Organisasi Sebagai Variabel Moderating." Universitas Soegiyapranata.

Solikhah, Badingatus. 2010. "Implikasi Intellectual Capital Terhadap Financial Perfomance, Growth, Dan Market Value; Studi Empiris Dengan Pendekatan Simplistic Specification.” In SNA XIII Purwokerto. Purwokerto.

Sugiwardani. 2012. "Analisis Pengaruh Partisipasi Anggaran, Informasi Simetris, Budaya Dan Komitmen Organisasi Terhadap Budgetary Slack."

Venusita. 2008. "Partisipasi Anggaran Dan Keterlibatan Kerja Dengan Komitmen Organisasi Sebagai Variabel Moderasi." Jurnal Kewirausahaan 2 (1): 1-13. 